University of Nebraska - Lincoln

DigitalCommons@University of Nebraska - Lincoln

Papers in Natural Resources

Natural Resources, School of

2018

\title{
Anthropogenic Hydrological Cycle Disturbance at a Regional Scale: State-Wide Evapotranspiration Trends (1979-2015) Across Nebraska, USA
}

Jozsef Szilagyi

University of Nebraska-Lincoln, jszilagyi1@unl.edu

Follow this and additional works at: https://digitalcommons.unl.edu/natrespapers

Part of the Natural Resources and Conservation Commons, Natural Resources Management and Policy Commons, and the Other Environmental Sciences Commons

Szilagyi, Jozsef, "Anthropogenic Hydrological Cycle Disturbance at a Regional Scale: State-Wide Evapotranspiration Trends (1979-2015) Across Nebraska, USA" (2018). Papers in Natural Resources. 970.

https://digitalcommons.unl.edu/natrespapers/970

This Article is brought to you for free and open access by the Natural Resources, School of at DigitalCommons@University of Nebraska - Lincoln. It has been accepted for inclusion in Papers in Natural Resources by an authorized administrator of DigitalCommons@University of Nebraska - Lincoln. 
Research papers

\section{Anthropogenic hydrological cycle disturbance at a regional scale: State-wide evapotranspiration trends (1979-2015) across Nebraska, USA}

Jozsef Szilagyi ${ }^{\text {a,b }}$

${ }^{a}$ Department of Hydraulic and Water Resources Engineering, Budapest University of Technology and Economics, Budapest, Hungary

${ }^{\mathrm{b}}$ Conservation and Survey Division, School of Natural Resources, University of Nebraska-Lincoln, Lincoln, NE, USA

\section{A R T I C L E I N F O}

\section{Article history:}

Received 13 September 2017

Received in revised form 21 December 2017

Accepted 23 December 2017

Available online 27 December 2017

This manuscript was handled by Marco

Borga, Editor-in-Chief, with the assistance of

Daniele Penna, Associate Editor

\section{Keywords:}

Complementary relationship of evaporation

Regional hydrologic cycle

ET ratio

Budyko curve

Water balance

High Plains aquifer

GRACE data

\begin{abstract}
A B S T R A C T
Trends in monthly evapotranspiration (ET) rates across Nebraska, the most intensely irrigated state within the US, were calculated by the calibration-free version of the nonlinear complementary relationship of evaporation over the 1979-2015 period utilizing North American Regional Reanalysis (NARR) net radiation, 10-m wind velocity, as well as Parameter Regression Independent Slope Model (PRISM) airand dew-point temperature data. State-averaged modeled ET rates rose by $5.5 \mathrm{~mm}$ decade $^{-1}$ due to the presence of wide-spread large-scale irrigation projects in accordance with a $2.4 \mathrm{~mm}$ decade ${ }^{-1}$ increase in PRISM precipitation $(P)$ and a simultaneous $-2.8 \mathrm{~mm} \mathrm{decade}^{-1}$ drop in United States Geological Survey's state-averaged annual streamflow rates, raising the state-wide ET to $P$ ratio from 0.89 to 0.91 over the modeled time-period. ET rates over irrigated crops increased by $7 \mathrm{~mm}$ decade $^{-1}$ despite a $-4.4 \mathrm{~mm}$ decade $^{-1}$ drop in precipitation rates. A similar increase in ET rates $\left(6 \mathrm{~mm}\right.$ decade $\left.{ }^{-1}\right)$ required $8.1 \mathrm{~mm}_{\text {decade }}{ }^{-1}$ increase in precipitation rates across the non-irrigated Sand Hills of Nebraska. Published NARR ET rates are unable to pick up this unusual regional trend. Since an increase in precipitation rates should normally decrease the ET ratio, as predicted by the Budyko curve, this study yields evidence on how dramatically sustained large-scale irrigation can alter the regional hydrologic cycle not only through a) trivially depleting streamflow rates and/or lowering groundwater table levels; b) suppressing precipitation locally (while enhancing it a long distance downwind), but also; c) reversing the trajectory of the regional ET ratio under generally increasing trends of precipitation.
\end{abstract}

(c) 2017 Elsevier B.V. All rights reserved.

\section{Introduction}

Irrigation worldwide is responsible for more than $85 \%$ of the global freshwater consumption (Gleick, 2003). As the population of the world is expected to grow steadily in the coming decades, so is the demand for improved crop yields which translates to a continual expansion of irrigated land area (Gleick, 2003). The crop fields of Nebraska, USA represent one of the world's most important agricultural lands due, not the least, to intensive irrigation, mainly via groundwater-pumping center pivot systems producing consistently high yields of corn and soybean, for example. In fact, Nebraska boasts the largest total of irrigated land within the coterminous United States surpassing the two largest states by area, Texas and California (USDA, 2012). This continued success in high crop yields over the past several decades is partly due to the fact that the High Plains aquifer, spreading under eight states, is the thickest and most extensive under Nebraska, where groundwater recharge rates are naturally enhanced (Szilagyi et al., 2011;

E-mail address: jszilagyi1@unl.edu
Szilagyi and Jozsa, 2013) by the loose and porous soils of the Sand Hills comprising about $1 / 3$ of the state's area (Fig. 1).

The hydrological effect of long-term large-scale irrigation however is felt not only locally in dropping streamflow rates (Szilagyi, 1999, 2001, 2014a) and/or groundwater levels (Korus et al., 2013), but also in areas as far as Illinois and Indiana (a distance of about $600-1000 \mathrm{~km}$ ) in the form of increased summer streamflow due to irrigation-enhanced evaporation over Nebraska and the resulting summer precipitation increases in the Midwest (DeAngelis et al., 2010; Kustu et al., 2011) downwind of irrigated areas. Similar findings were reported over the Great Plains by Barnston and Schickedanz (1984), Moore and Rojstaczer (2002) and Huber et al. (2014). As a result, the question arises if indeed sustained large-scale irrigation has increased regional evapotranspiration (ET) rates over Nebraska noticeably, and if so, whether it can be detected by taking advantage of the latest developments in evaporation research utilizing available large-scale and long-term meteorological data. The fact that such a teleconnection between irrigation and the resulting summer streamflow-rate increase a long distance away has only been detected recently, can partially 


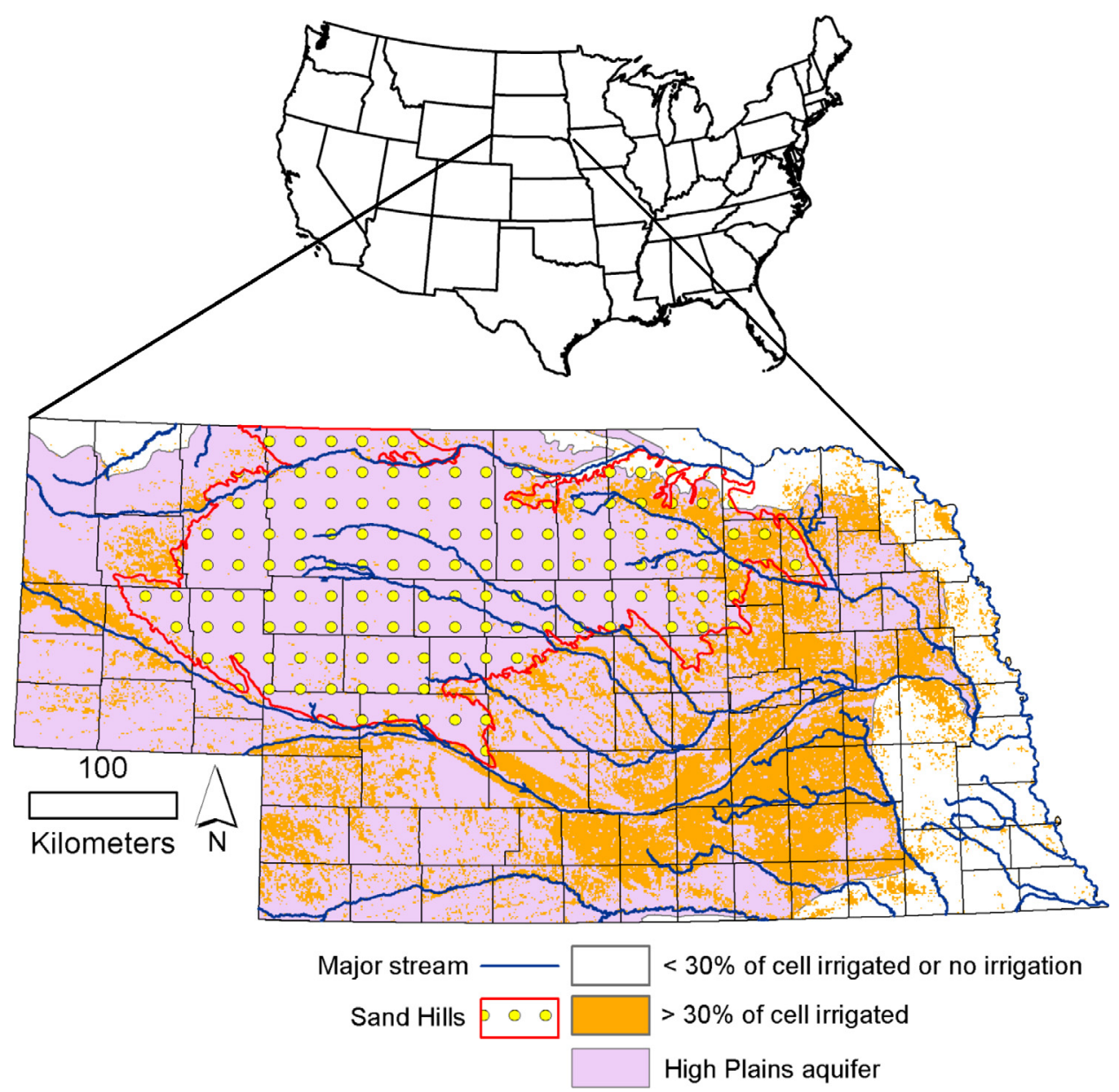

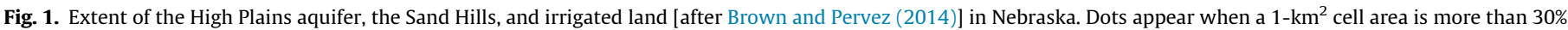
irrigated land. The straight lines are county boundaries.

be attributed to the about $50 \%$ increase [from $\sim 23,000$ to $\sim 34,000$ $\mathrm{km}^{2}$ (USDA, 2012)] in irrigated land area within Nebraska over the 1979-2015 period for which meteorological data exist for the present study. Note that any approach that requires surface flux measurements, remote sensing, and/or land use/cover data was deliberately excluded for the present analysis. This is so because such data a) are not available on a long-term basis [e.g., Moderate Resolution Imaging Spectroradiometer (MODIS)]; b) not continuous (e.g., the snap-shots of LANDSAT and land use/cover maps); c) lead to a mismatch of scales, like flux data that are valid at the plot scale (and not at the regional scale of the current ET approach), and/or; d) require empirical relationships (e.g., the transformation of a vegetation index to ET) that often need site-specific calibration (Mutiibwa and Irmak, 2013; Kukal et al., 2017).

This study is rather based on the latest advances (Crago et al., 2016; Szilagyi et al., 2017) of the complementary relationship (CR) (Bouchet, 1963) of evaporation. The Szilagyi et al. (2017) formulation of the CR has the distinct advantage that it only requires widely available atmospheric/radiation variables and it is calibration-free. The latter is especially valuable when the modeling period --over which environmental parameters (such as related to land use, land cover) that typically serve as boundary conditions for the model may change significantly-- is long, thus requiring repeated recalibration or readjustment of the parameters during the model run.

Finally, the results of the present study are to be evaluated by a long-term water balance approach and also compared to the widely available North American Regional Reanalysis (NARR) ET rates provided by the Land Surface Model (LSM) (Mesinger et al., 2006) of NARR. Besides long-term averages, reliability of the annual values is to be tested with the help of the Gravity Recovery and Climate Experiment (GRACE) data (Tapley et al., 2004).

\section{Methods}

The complementary relationship (CR) of evaporation recognizes that at a suitable time-scale (typically one day or longer) the lower atmosphere will adjust to the moisture status of the homogeneous land (Crago et al., 2017), the latter regulating actual ET rates which then can be derived solely from atmospheric and radiation observations without the need of explicit knowledge of surface properties, such as vegetation cover type and height, or leaf area index. For a history and explanation of the original CR concept, see Brutsaert (1982).

The dimensionless version of the $\mathrm{CR}$, as was recently generalized by Brutsaert (2015), and improved upon by Crago et al. (2016) and Szilagyi et al. (2017) can be given as

$y=(2-X) X^{2}$

where the scaled variables are defined the following way: $y=E T / E_{p}$, and $X=\left(E_{p \max }-E_{p}\right)\left(E_{\text {pmax }}-E_{w}\right)^{-1} E_{w} / E_{p}$. Here $E_{p}\left(\mathrm{~mm} \mathrm{~d}^{-1}\right)$ is the Penman (1948) evaporation rate of a small wet patch or open water surface, specified as

$E_{p}=\frac{\Delta\left(T_{a}\right)}{\Delta\left(T_{a}\right)+\gamma} R_{n}+\frac{\gamma}{\Delta\left(T_{a}\right)+\gamma} f_{u}\left[e^{*}\left(T_{a}\right)-e^{*}\left(T_{d}\right)\right]$ 
where $T_{a}(\mathrm{~K})$ and $T_{d}(\mathrm{~K})$ are the air- and dew-point temperatures, respectively, $\Delta\left(\mathrm{hPa} \mathrm{K}^{-1}\right)$ the slope of the saturation vapor pressure curve evaluated at $T_{a}, \gamma\left(\mathrm{hPa} \mathrm{K}{ }^{-1}\right)$ the psychrometric constant, $R_{n}$ the surface net radiation expressed in water equivalents $(\mathrm{mm}$ $\left.\mathrm{d}^{-1}\right), e^{*}(\mathrm{hPa})$ the saturation vapor pressure, and $f_{u}\left(\mathrm{~mm} \mathrm{~d}^{-1} \mathrm{hPa}^{-1}\right)$ the wind function, traditionally formulated as $0.26\left(1+0.54 u_{2}\right)$, where $u_{2}\left(\mathrm{~m} \mathrm{~s}^{-1}\right)$ is the horizontal wind speed $2 \mathrm{~m}$ above the ground.

The evaporation rate, $E_{w},\left(\mathrm{~mm} \mathrm{~d}^{-1}\right)$ of a wet surface with a regional extent, on the other hand, can be described by the Priestley and Taylor (1972) equation as

$E_{w}=\alpha \frac{\Delta\left(T_{w}\right)}{\Delta\left(T_{w}\right)+\gamma} R_{n}$

where $\alpha(-)$ is the Priestley-Taylor coefficient, often having an empirical value between 1.1 and 1.3 , and $T_{w}(\mathrm{~K})$ the wetenvironment air temperature. This is the temperature the air would assume under the same $R_{n}$ and wind conditions valid for (2) except that the land surface is completely wet on a regional scale. As this latter temperature is not known under typically drying conditions, it can be approximated by the wet-environment surface temperature, $T_{w s}(\mathrm{~K})$ (under humid conditions the vertical air temperature gradient is relatively small in comparison with drying conditions), as long as the latter is smaller than $T_{a}$, otherwise $T_{w}$ can be replaced by $T_{a}$ since in reality $T_{w} \leq T_{a}$ due to the cooling effect of evaporation (Szilagyi, 2014b). $T_{w s}$, however, can be obtained implicitly (Szilagyi, 2014b) from the Bowen-ratio, $B_{o}(-)$, of the small wet patch (2) is applied for, as

$B_{o}=\frac{H}{L E} \approx \frac{R_{n}-E_{p}}{E_{p}} \approx \gamma \frac{T_{w s}-T_{a}}{e^{*}\left(T_{w s}\right)-e^{*}\left(T_{d}\right)}$

where $H\left(\mathrm{~W} \mathrm{~m}^{-2}\right)$ is the sensible, and $L E\left(\mathrm{~W} \mathrm{~m}^{-2}\right)$ the latent heat flux at the small, wet surface.

$E_{\text {pmax }}$ in the definition of $X$ is the maximum value of $E_{p}$ under the same radiation and wind conditions valid for (2) except that now the environment is totally devoid of any moisture (Szilagyi et al., 2017), i.e.,

$E_{p \max }=\frac{\Delta\left(T_{d r y}\right)}{\Delta\left(T_{d r y}\right)+\gamma} R_{n}+\frac{\gamma}{\Delta\left(T_{d r y}\right)+\gamma} f_{u} e^{*}\left(T_{d r y}\right)$.

Here $T_{d r y}(\mathrm{~K})$ is the dry-environment air temperature the moist air would assume during adiabatic drying of the surface (Szilagyi et al., 2017)

$T_{d r y}=T_{w b}+\frac{e^{*}\left(T_{w b}\right)}{\gamma}$

where $T_{w b}$ is the wet-bulb temperature. $T_{w b}$ can be obtained from the same adiabatic process (Monteith, 1981; Szilagyi 2014b) occurring at the wet-bulb thermometer, yielding another implicit equation, similar to (4), i.e.,

$\gamma \frac{T_{w b}-T_{a}}{e^{*}\left(T_{w b}\right)-e^{*}\left(T_{d}\right)}=-1$

Szilagyi et al. (2017) reported that (1) through (7), employing long-term averages of monthly variables, outperformed earlier calibrated versions (Brutsaert, 2015; Szilagyi, 2015; Szilagyi et al., 2016) of the generalized CR due to its improved scaling of the dimensionless variables, and correctly accounted-for moisturelimit conditions. Szilagyi et al. (2017) described a procedure of how the value of the Priestly-Taylor $\alpha$ of (3) can be obtained without calibration, yielding $\alpha=1.13$, employing long-term monthly averages of the latest meteorological normal-period (i.e., 19812010). In a recent continuous, monthly simulation of the cotermi- nous US ET values (Szilagyi, 2017b) over the current modeling period (i.e., 1979-2015), $\alpha$ assumed a value of 1.15 which was kept for the present study.

\section{Study area and data}

The state of Nebraska lies in the central Great Plains, with a strong gradient in mean annual precipitation from the subhumid south-eastern border of more than $850 \mathrm{~mm}$ to less than $350 \mathrm{~mm}$ in the panhandle. From the continental climate of the state follows the hot summers with July mean daily temperatures of $23.6{ }^{\circ} \mathrm{C}$ and cold winters of $-5.5^{\circ} \mathrm{C}$ in January (Frankson et al., 2017). Precipitation is highly variable from year to year, with the statewide annual average ranging from a low of $340 \mathrm{~mm}$ in 2012 to a high of $900 \mathrm{~mm}$ in 1915 (Frankson et al., 2017). Most of the precipitation falls during the spring and summer months, but seasonal precipitation varies widely (Frankson et al., 2017). 2012 was Nebraska's driest year on record. Statewide summer precipitation averaged only $95 \mathrm{~mm}$, well below the historical average of 240 $\mathrm{mm}$. By the end of September, over $75 \%$ of the state was experiencing exceptional drought conditions, putting extremely high demand for irrigation water. The drought, combined with the extreme summer heat, had significant negative impacts on nonirrigated crop yields and pasture conditions (Frankson et al., 2017).

The continuous estimation of the state-wide ET rates via (1)-(7) require air- $\left(T_{a}\right)$ and dew-point $\left(T_{d}\right)$ temperatures, surface net radiation $\left(R_{n}\right)$ and 2-m wind $\left(u_{2}\right)$ data, the averages of which were supplied at a monthly time-step over the 37-year period of 1979-2015 at the 4-km spatial resolution of the $T_{a}$ and $T_{d}$ values coming from the Parameter-Elevation Regressions on Independent Slopes Model (PRISM) (Daly et al., 1994). The 32-km spatial resolution monthly NARR LSM $R_{n}, 10-\mathrm{m}$ wind ( $\left.u_{10}\right)$, and ET (for comparison only) values (available since 1979) were downloaded from the NOAA website: www.esrl.noaa.gov/psd/data/gridded/data.narr.html. See Mesinger et al. (2006) for a detailed description of how the ET rates were derived by the NARR LSM. The $R_{n}, u_{10}$ and ET values were further interpolated linearly onto the PRISM grid employing a power transformation (Brutsaert, 1982) of the $u_{10}$ values into $u_{2}=$ $\mathrm{u}_{10}(2 / 10)^{1 / 7}$, required by (2) and (5).

The obtained long-term ET rates and their linear trends are to be validated as the difference in long-term PRISM precipitation $(P)$ and United States Geological Survey's (USGS) 8-level Hydrologic Unit Code (HUC8, Fig. 2) streamflow (Q) values (waterwatch.usgs.gov), i.e., $P-Q$. Here it is assumed that changes in groundwater and soil moisture $(\Delta S)$ between the end and start of the 37 years of the model period are negligible in comparison with the incoming $(P)$ and outgoing $(Q)$ fluxes for each HUC8 watershed. The $\mathrm{ET} \approx P-Q$ estimation further assumes that inter-basin water transfers are also negligible, and that the net lateral groundwater flux is zero for each catchment. This latter assumption is probably the most problematic, considering the layout of the High Plains aquifer (Korus et al., 2013) where the continuous unconfined groundwater table has an east-ward general slope of about 1:500 (Fig. 2) under Nebraska, creating a complex flow-net for the groundwater, first described by Toth (1963). The regional westto-east slope of the terrain may lead to discrepancies in watershed boundaries between surface and subsurface water, making the watersheds similar to flow-through lakes: gaining water on one side and losing on the other, without any guarantee that the difference is zero. Consequently, validation of the modeled ET rates and their trends will eventually be performed for the entire state of Nebraska, by spatial averaging of the HUC8 watershed fluxes. The long-term water balance equation for the entire state thus becomes

$\langle E T\rangle=\langle P\rangle-\langle Q\rangle+G_{\text {in }}-G_{\text {out }} \approx\langle P\rangle-\langle Q\rangle$ 


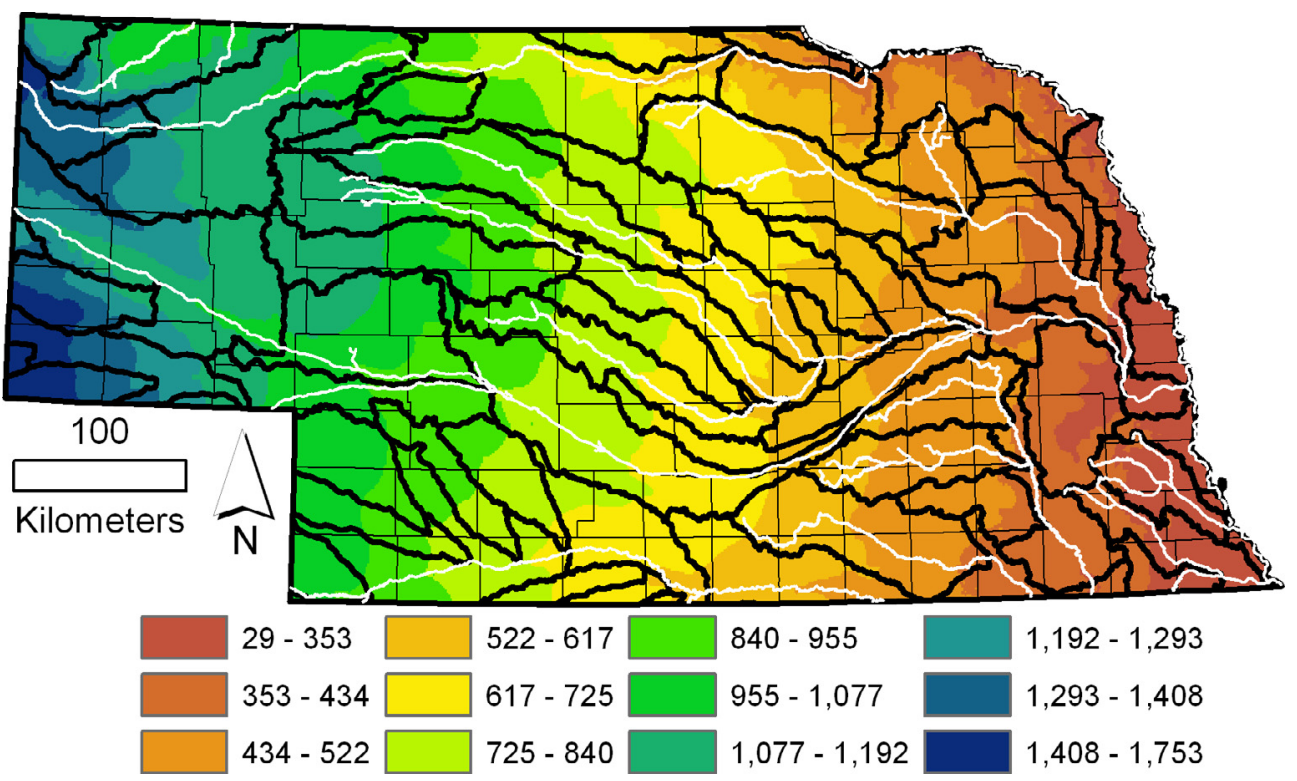

Fig. 2. General configuration of the regional groundwater table ( $m$ above mean sea level) and HUC8 watershed boundaries in Nebraska.

where $G$ is the lateral regional groundwater flux in and out of the state and the sharp brackets denote state-wide averages for 1979-2015. Here again long-term storage change in the groundwater was assumed negligible, so was any vertical flux exchange between the unconfined High Plains and the underlying confined aquifers. A rough estimate of the magnitude of $G$ can be obtained from state-wide maps of transmissivity and elevation of the groundwater table (Korus et al., 2013) using Darcy's law, yielding a value of about a few mm annually, which is negligible (and even more so the difference in $G_{\text {in }}$ and $G_{\text {out }}$ ) in comparison with the 548 $\mathrm{mm} \mathrm{yr}^{-1}$ mean annual state-wide ET rate reported by Szilagyi (2017a) for the 1981-2010 period. At the smaller scale of the HUC8 watersheds hydraulic gradients and especially transmissivity values in the Sand Hills (Korus et al., 2013) may be much larger and more spatially variable (due to a much increased saturated hydraulic conductivity value of the sand and the largest saturated thickness of the entire High Plains aquifer) than what is found at the eastern or western boundary of the state, producing potentially non-negligible $G$ values there.

To further test the reliability of the state-wide annual ET values, annual changes in the GRACE-derived terrestrial water storage $\left(S_{G}\right)$ values (Tapley et al., 2004) for Nebraska over the available 20022015 time period are also to be compared with water-balance derived similar changes $(\Delta S)$ as (note that at the annual scale $\Delta S$ may not be negligible)

$\Delta S=P-Q-E T$

The $S_{G}$ values obtained by NASA's Jet Propulsion Laboratory can be downloaded from http://ccar.colorado.edu/grace/jpl.html. The state of Nebraska is covered by six so-called GRACE mascons, therefore the state-wide $S_{G}$ values are obtained by weighting the individual mascon values with their shared areas with Nebraska. For obtaining annual changes, the original $S_{G}$ values, available for certain days of the year, are interpolated by a spline method to yield a value for each day of the 2002-2015 period. The annual changes, $\Delta S_{G}$, then result by taking the difference in the $S_{G}$ values for January 1 in each consecutive years. For 2002, the first available published value is used in lieu of the January 1 value.

\section{Results and discussion}

\subsection{Mean annual averages}

Eqs. (1)-(7), employed with monthly PRISM $T_{a}, T_{d}$, and NARR $R_{n}$ and $u_{10}$ values, yield actual monthly ET rates at the $4-\mathrm{km}$ spatial resolution of PRISM for the 1979-2015 time period (Fig. 3). ET rates largely follow the spatial distribution of precipitation (Fig. 4): the largest values are found in the moist south-eastern corner of the state where precipitation is most abundant, while the smallest rates can be observed in the dry north-western corner, along with the scarcest precipitation. The state-wide mean ET ratio (i.e., ET $P^{-1}$ ) from the two spatial averages (i.e., $538 \mathrm{~mm} \mathrm{yr}^{-1}$ for ET and $597 \mathrm{~mm} \mathrm{yr}^{-1}$ for $P$ ) becomes $90 \%$. Fig. 5 displays the spatial distribution of the mean annual ET ratios.

As expected, the ET ratios are the smallest in the eastern part of the state where precipitation is the highest, since more abundant precipitation typically generates more runoff, as soil moisture is kept closer to saturation, thus leaving relatively less (but in absolute terms more, of course) for ET (Budyko, 1974). With the decrease in precipitation by going west, the ET ratios increase, in certain areas well above $100 \%$. These areas (in bluish color) generally correspond to irrigated land (Fig. 1) or marshlands of the Sand Hills (Fig. 5), but only when precipitation is less than $400 \mathrm{~mm} \mathrm{yr}^{-1}$ (roughly west of the 100th meridian which crosses the state just to the right of the eastern border of its largest county, i.e., Cherry, in north-central Nebraska) as was previously found by Szilagyi et al. (2017) for the entire coterminous US, with very few exceptions.

Naturally, small marshlands, lakes or heavily irrigated crops can evaporate locally at a rate exceeding even $700 \mathrm{~mm} \mathrm{yr}^{-1}$ in Nebraska (Szilagyi et al., 2011b), but it will not necessarily show up in the 4-km spatial resolution of the PRISM data, especially when one further considers the spatial density of the $T_{a}$ and $T_{d}$ stations, displayed in Fig. 5, that serve the basis of the PRISM grid values. Intensive irrigation certainly corresponds to elevated ET ratios in south-central Nebraska, south of the Sand Hills (green colors in Fig. 5), but elevated air temperatures (Fig. 6) also play a role, leaving less to runoff, even though precipitation rates (Fig. 4) are about the same as in the Sand Hills. 


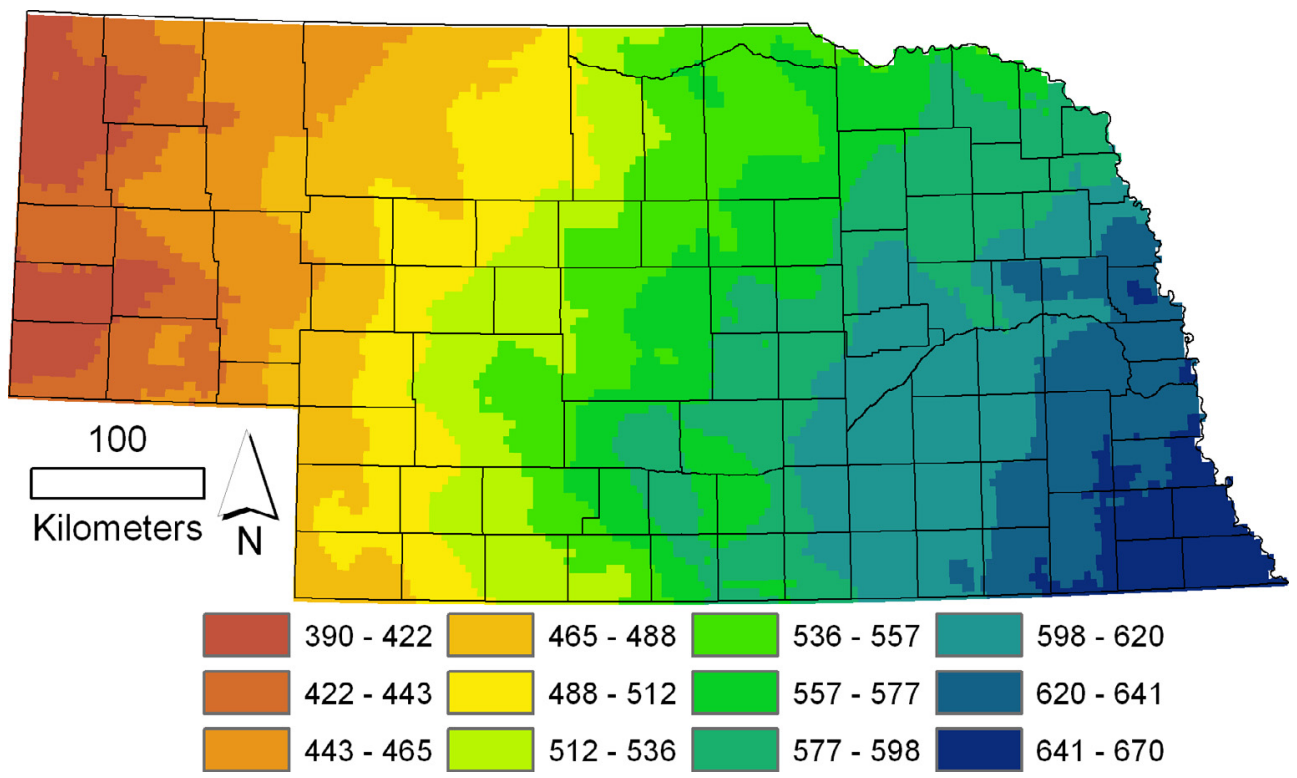

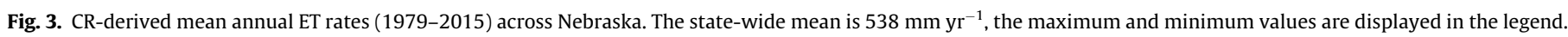

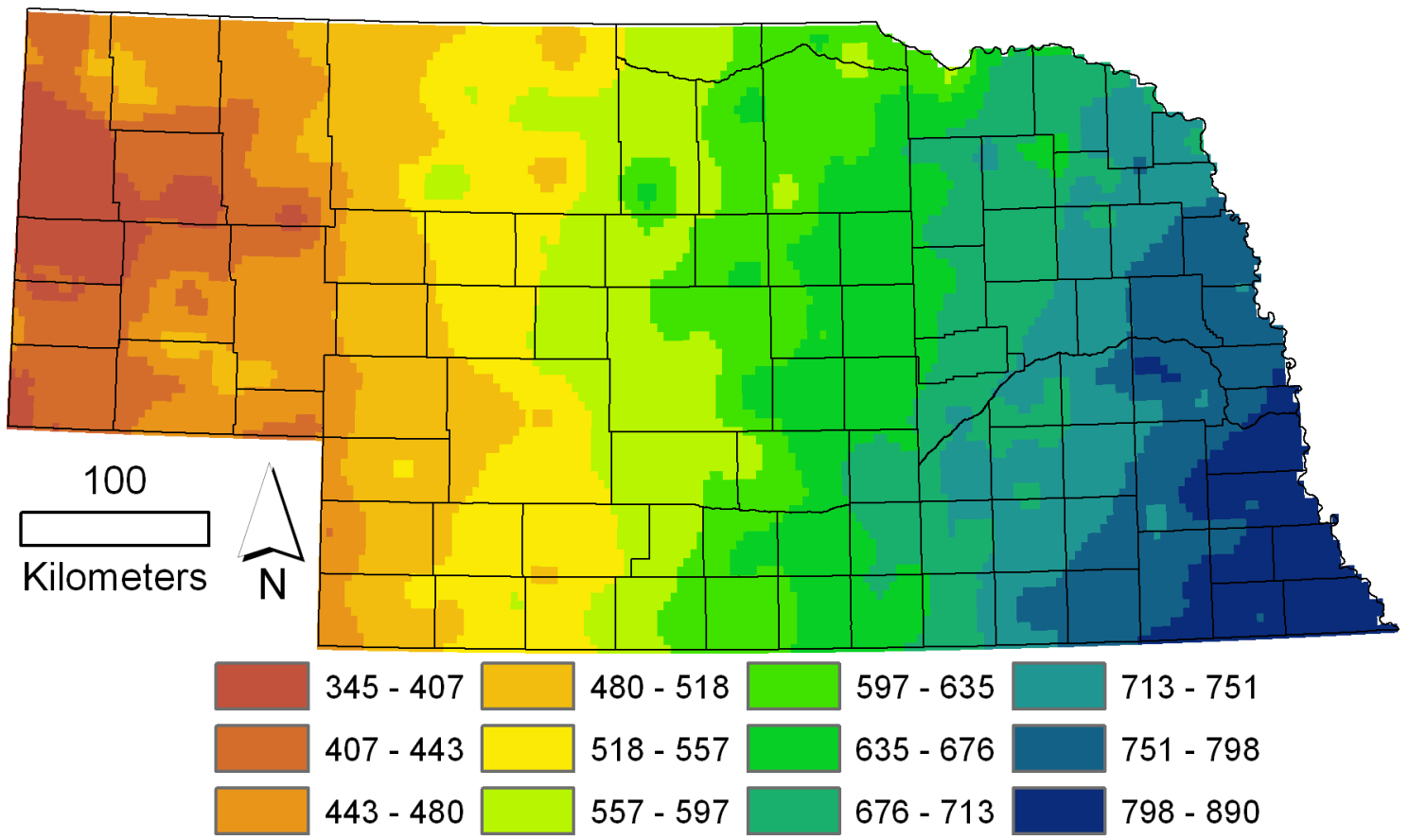

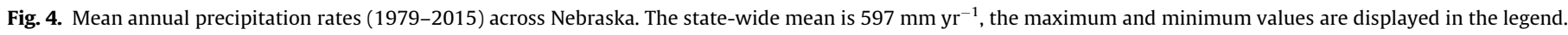

Modeling results were validated by simplified water balances written for the HUC8 catchments as $\mathrm{ET} \approx P-Q$ displayed in Fig. 7. While the general increasing tendency from north-west to south-east is present in the $P-Q$ values, similar to Fig. 3, the largest catchment-wide ET rates (surpassing the CR-derived maximum) do not occur in the wettest south-easternmost tip of the state, but north of it, in an area with negligible irrigation (Fig. 1), next to a catchment with an ET rate $100 \mathrm{~mm} \mathrm{yr}^{-1}$ less.

For the whole state the two estimates ( 538 vs $547 \mathrm{~mm} \mathrm{yr}^{-1}$ ) differ by less than $2 \%$, which is remarkable, considering that CRderived ET rates were obtained without any calibration or explicit information about precipitation, soil-type, irrigation, moisture conditions or vegetation. Fig. 8 displays the regression plot between the two ET estimates obtained for the HUC8 catchments in Nebraska. While the CR model explains $94 \%\left(=R^{2}\right.$ in percentages) of the variation (a remarkably high value) found in the mean annual water-balance ET rates with a root mean squared error (RMSE) of $31.4 \mathrm{~mm} \mathrm{yr}^{-1}$, it underestimates water-balance ET by $7 \%$ at the $P-Q$ value of $700 \mathrm{~mm}$, and overestimates it by $6 \%$ at $400 \mathrm{~mm}$. The two largest $P-Q$ values of the dark-blue catchments of Fig. 7 (with $Q$ values of about $38 \mathrm{~mm} \mathrm{yr}^{-1}$ only, in a neighborhood of 93, 129, 150 and $172 \mathrm{~mm} \mathrm{yr}^{-1}$ runoff values) are clear outliers and were left out from the line fitting and performance analysis.

In order to test the reliability of the modeled annual ET values on which the ensuing trend analysis is based, the state-wide 


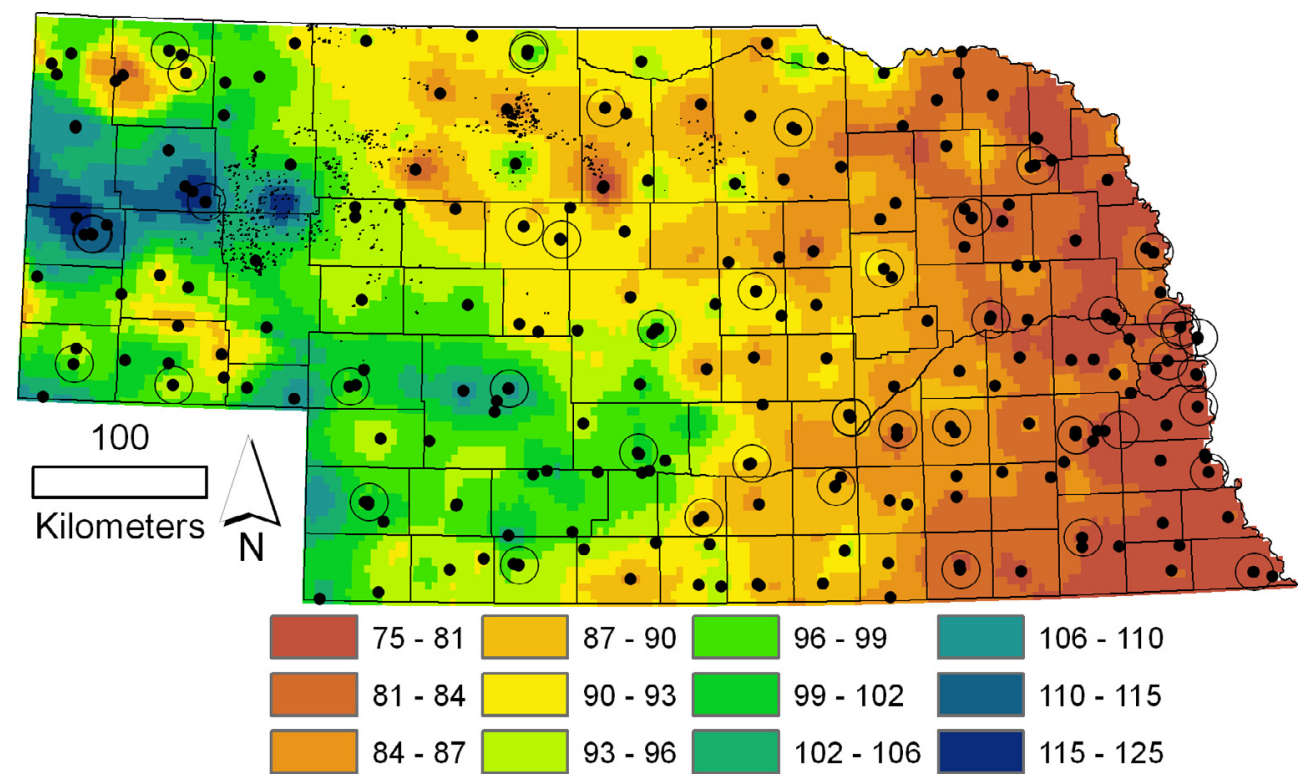

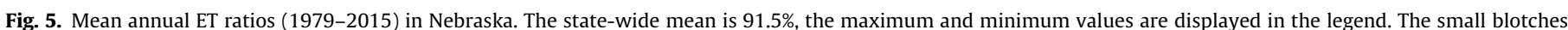

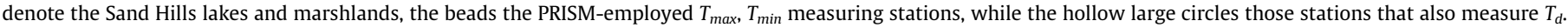
Note that $0.915=\langle\mathrm{ET} / P\rangle$ is larger than $\langle\mathrm{ET}\rangle /\langle P\rangle=0.9$. For a state-wide mean ET ratio value the latter definition is more appropriate.

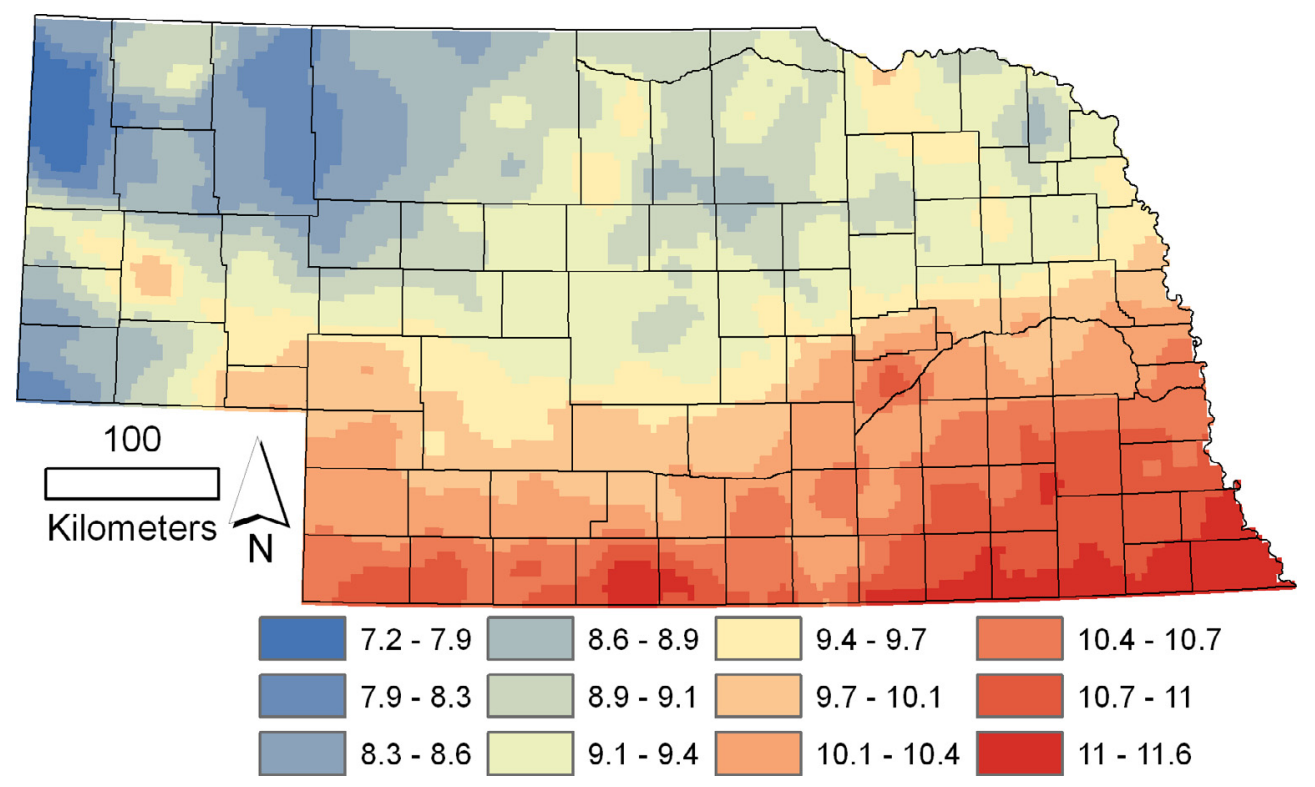

Fig. 6. Mean annual air temperature (1979-2015) in Nebraska. The state-wide mean is $9.57{ }^{\circ} \mathrm{C}$, the maximum and minimum values are displayed in the legend.

annual $\Delta S$ estimates of (9) were compared to the GRACE-obtained values of similar annual water storage changes, $\Delta S_{G}$, for the available 2002-2015 time period (Fig. 9) and yielded a statistically significant linear correlation coefficient $(R)$ value of 0.74 . It is remarkable again how accurately the maximum and minimum values of $\Delta S_{G}$ are captured by $\Delta S$ in the second wettest (i.e., 2007) and the driest (i.e., 2012) years, respectively, as defined by precipitation amount, without any kind of model calibration and by considering that the $\Delta S_{G}$ values are just a fraction of the modeled ET rates.

\subsection{Linear trend analysis}

With 37 years of data it is possible to check if annual ET rates in Nebraska have expressed any long-term tendencies over the course of the 1979-2015 time period in the light of increasing air temperatures (e.g., Cox et al., 2000; Held and Soden, 2006) globally and significant increases in irrigated area regionally. Dai et al. (2016) found a $0.15{ }^{\circ} \mathrm{C}$ per decade air temperature increase among the Midwest states (including Nebraska) during the growing seasons of 1980-2013. Mahmood et al. (2008) found that growing season $T_{d}$ can be $1.56^{\circ} \mathrm{C}$ higher over irrigated land than over rain-fed crops in Nebraska, a clear indication that large-scale irrigation affects the moisture content of the air at a regional scale.

Analysis of the PRISM air temperature data indeed yields an overall increase in annual air temperatures across Nebraska (Fig. 10) over the 1979-2015 period. The trend in each PRISM grid-point was obtained as the slope of the best-fit first order polynomial curve over the 37 annual mean values. In general, the eastern part (east of the 100th meridian) of the state has cooled 


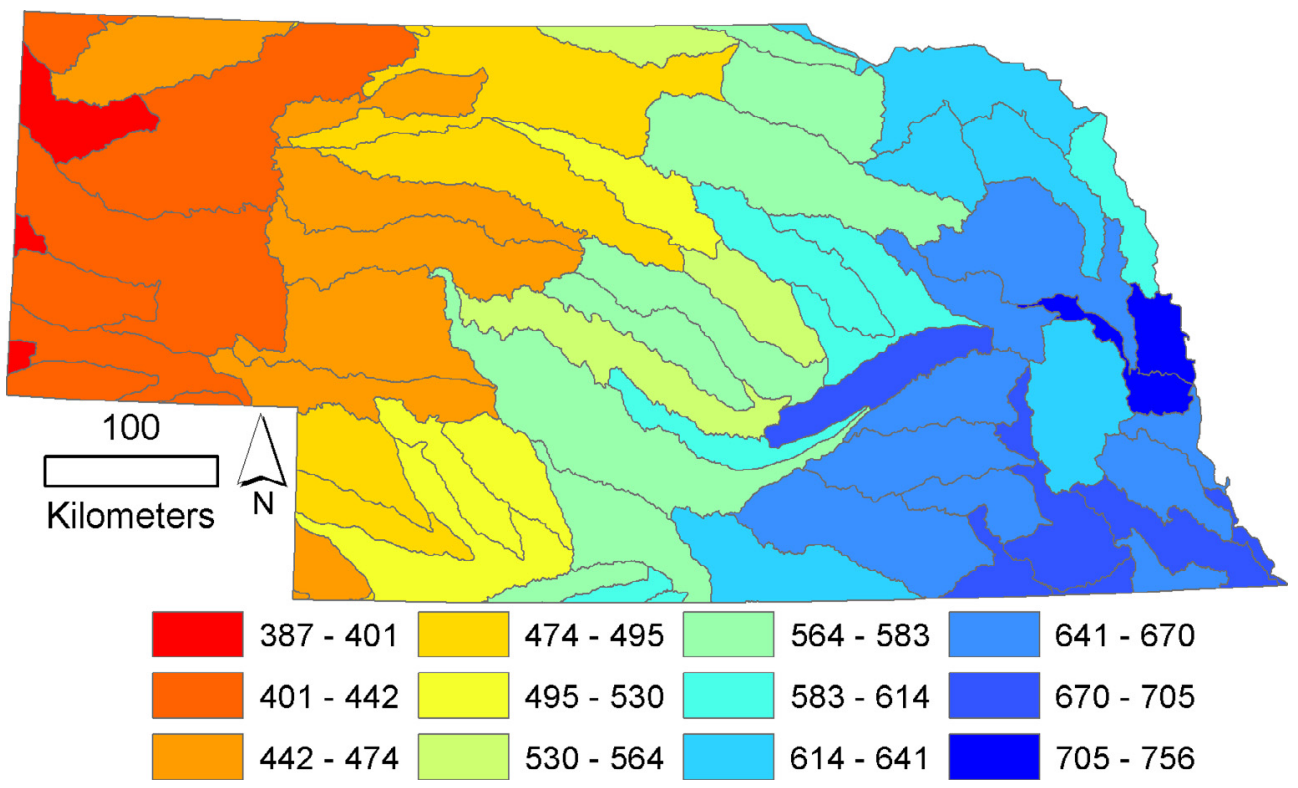

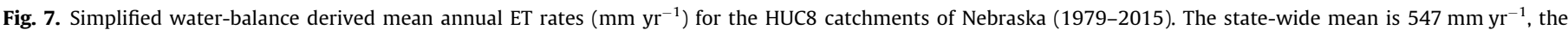
maximum and minimum values are displayed in the legend.

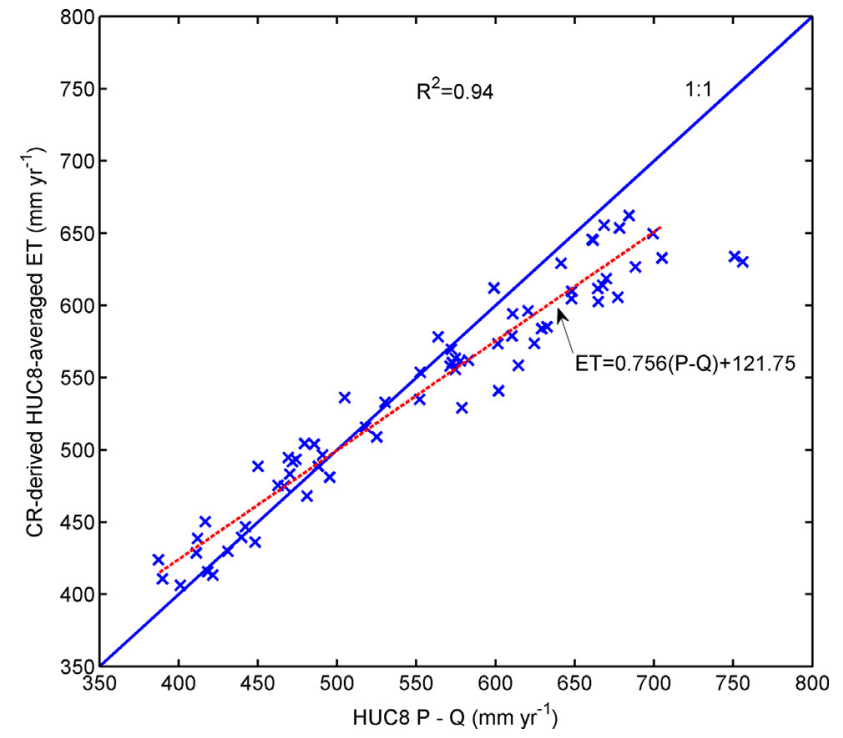

Fig. 8. Regression plot of water-balance (i.e., $P-Q$ ) and CR-derived mean annual HUC8 catchment ET rates (1979-2015) in Nebraska with the best-fit line (red) displayed.

somewhat while the rest warmed up. The $T_{d}$ values express double the warming trend of $T_{a}$ (Fig. 11), practically with stagnating or rising values everywhere. Interestingly the largest increase is found in north-central Nebraska, around the town of Valentine in Cherry County, seemingly not connected to any large-scale irrigation project.

Not only temperatures increased in the 1979-2015 period, but the amount of annual precipitation as well (Fig. 12), although spatially unevenly. Over the cooling eastern part of the state (Fig. 10) with the most abundant irrigation (Fig. 1), precipitation has generally decreased (Fig. 12), possibly due to the cooling effect of irrigation-enhanced evaporation over expanding irrigation projects which then stabilizes the atmosphere over these extensive irrigated areas, similar to what is known over the Great Lakes where summer precipitation is reduced by as much as $20-30 \%$

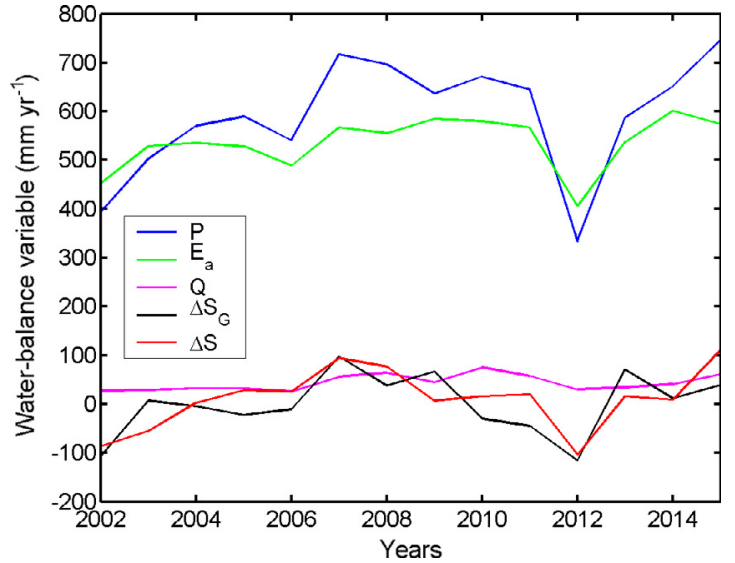

Fig. 9. Annual state-wide values of the variables in (9) together with GRACEderived annual changes $\left(\Delta \mathrm{S}_{\mathrm{G}}\right)$ in the stored water volume in Nebraska during 2002 2015. $\Delta \mathrm{S}$ explains $55 \%$ of the variance in the $\Delta \mathrm{S}_{\mathrm{G}}$ values. The mean of $\Delta \mathrm{S}_{\mathrm{G}}$ is -0.2 $\mathrm{mm} \mathrm{yr}^{-1}$ which indicates no change in state-wide stored water volume during 2002-2015.

(Changnon and Jones, 1972; Bates et al., 1993) by the cold water surface. In the most heavily irrigated cells marked below in Fig. $14, P$ on average decreased by as much as $4.4 \mathrm{~mm}$ decade $^{-1}$. To the best knowledge of the author this is the first report of the possibility of a link between expanding irrigated areas and reduced precipitation rates locally within the US. Direct comparison of precipitation rates over irrigated and non-irrigated areas is hindered by the strong east-to-west gradient in precipitation and the uneven distribution of irrigated land across the state.

As one would expect, with increases in state-wide precipitation, air- and dew-point temperatures, ET rates have also increased in general (Fig. 13) at an average rate of $5.47 \mathrm{~mm} \mathrm{decade}^{-1}$, more than doubling the rate of the precipitation increase $(2.44 \mathrm{~mm}$ decade $^{-1}$ ). The modeled $5.47 \mathrm{~mm}$ decade $^{-1}$ state-wide ET trend value is within $4.2 \%$ of the water-balance derived trend (i.e., the difference in trends of the state-wide annual $P$ and $Q$ values, see Table 1) of $5.25 \mathrm{~mm}$ decade $^{-1}$, which is again a remarkable achievement, similar to that of the state-wide mean annual ET 


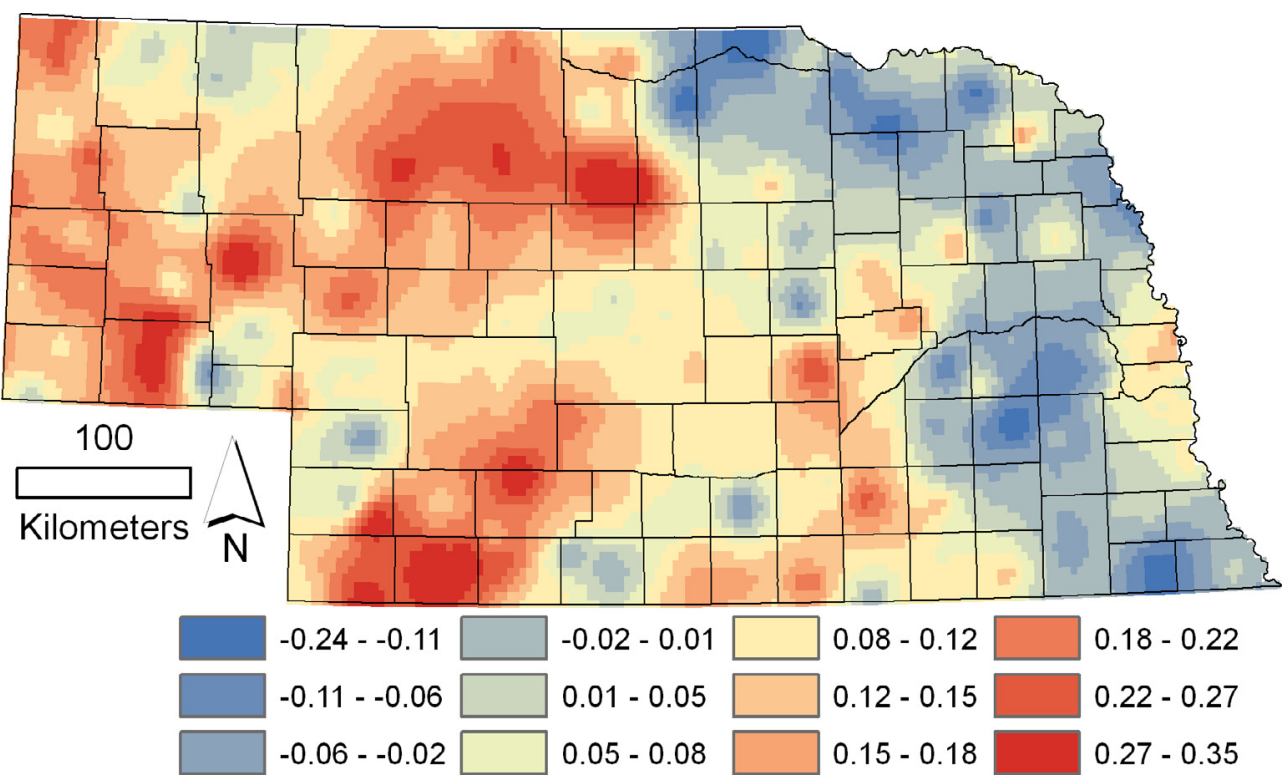

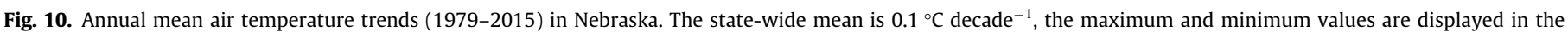
legend.

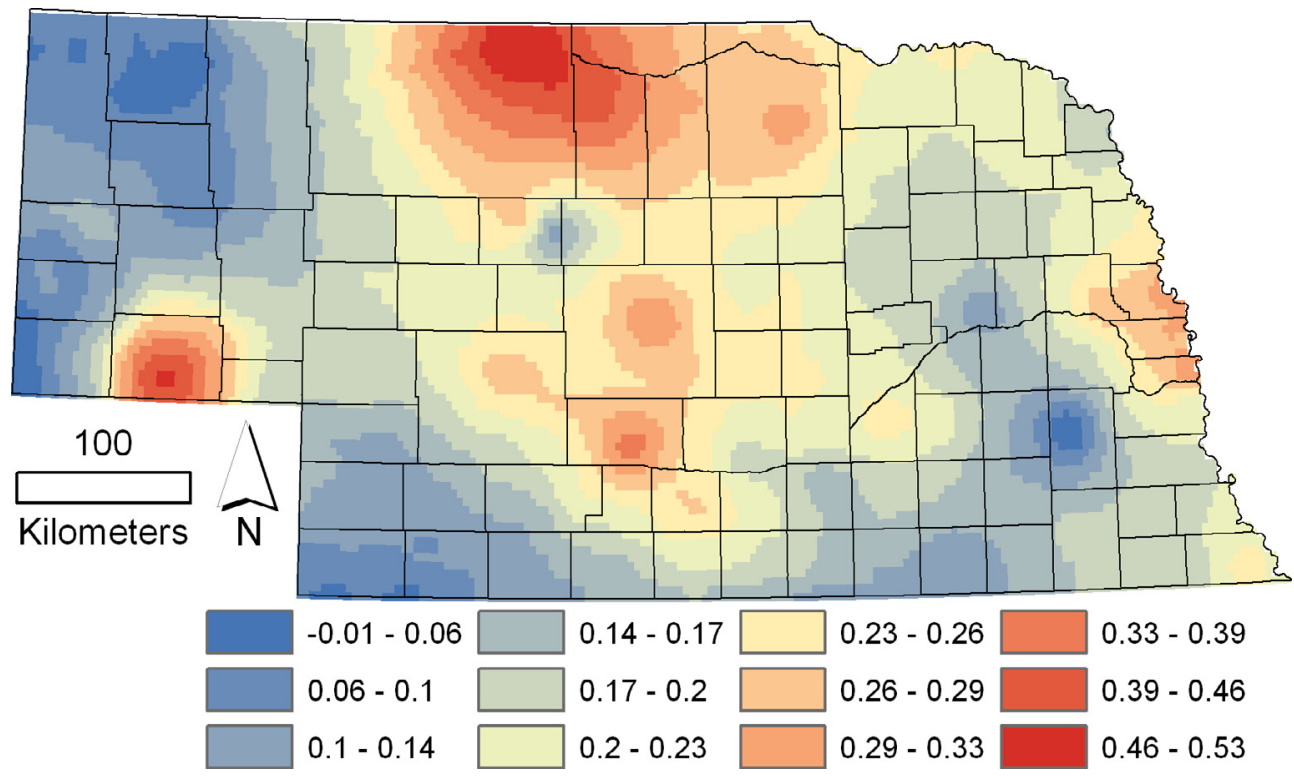

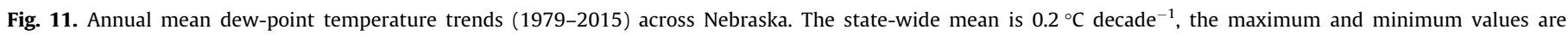
displayed in the legend.

estimate, considering that no model calibration whatsoever was performed. Over the heavily irrigated cells of Fig. 14, ET rates on average have increased by $7 \mathrm{~mm}$ decade $^{-1}$ (with a simultaneous $-4.4 \mathrm{~mm}$ decade $^{-1}$ decline in precipitation rates).

Only the panhandle region of Nebraska and the Republican River basin in the south-west have displayed declining ET rates, exactly in the regions where dew-point temperatures remained stagnant overall (Fig. 11) despite a warming trend. Note that a decreasing ET trend does not necessarily translate into a declining $T_{d}$ trend (and vice versa). This is so because how much moisture the air contains at a given distance from the ground depends not only on the ET flux but simultaneously on the wind characteristics (annual mean wind velocities stayed constant over Nebraska) which not only affect the moisture profile but also the residence time of moisture in the air. With increasing air- but steady dew- point temperatures (and wind speed) in the two areas (Figs. 10 and 11) the relative humidity has declined, favoring longer residence time for water vapor which means that the same moisture level may be maintained by lower ET rates.

Kukal et al. (2017), using calibrated crop-coefficients, found a similar spatial pattern of growing season ET trends for corn and soybean in Nebraska over the 1982-2013 period: with overall increases across the state except in the panhandle region and in the middle of the state (near the south-east corner of Cherry County), exactly where in Fig. 13 the greenish-yellow patch is found. Their data however does not show declining trends in the Republican River basin, i.e., in the south-western part of Nebraska.

The downloadable NARR LSM ET data, however, not only overestimates the statewide water-balance derived mean annual ET rate of $547 \mathrm{~mm} \mathrm{yr}^{-1}$ by $73 \mathrm{~mm} \mathrm{yr}^{-1}$ (a 15\% error) and even the 


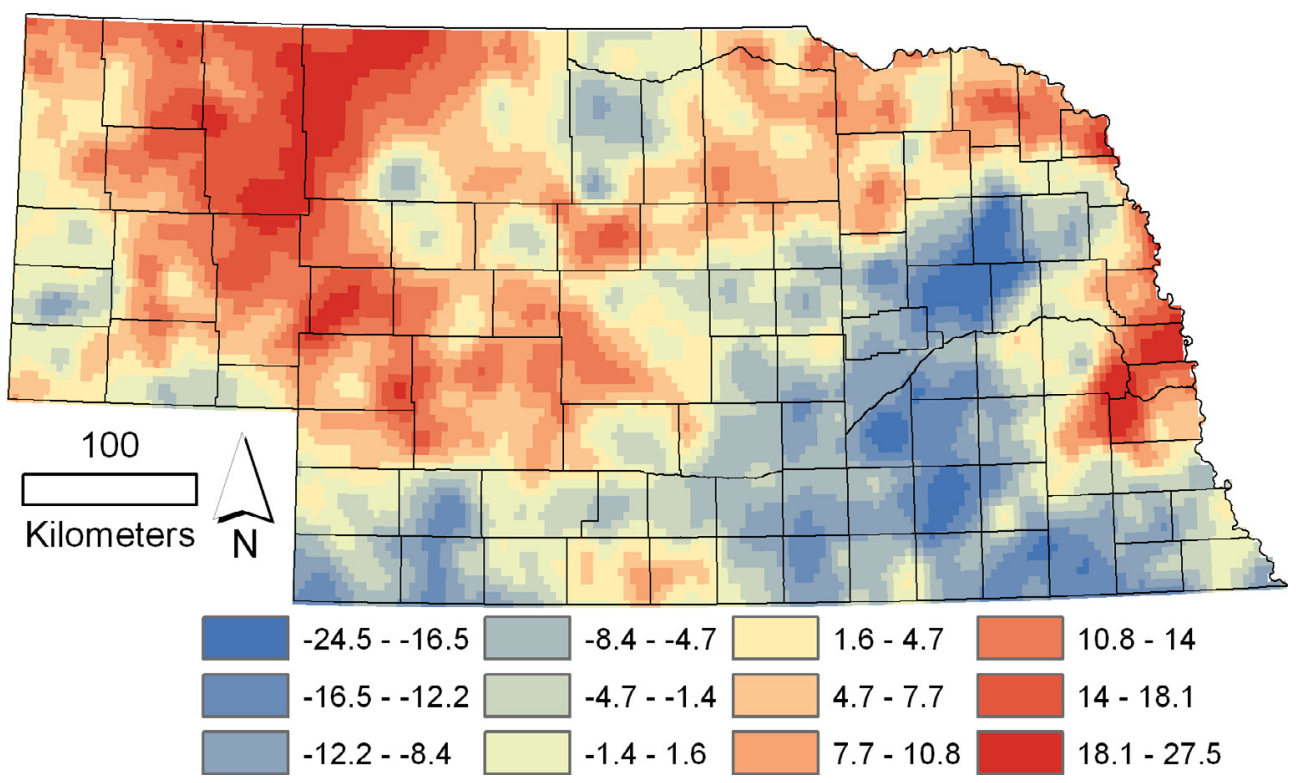

Fig. 12. Annual precipitation trends (1979-2015) across Nebraska. The state-wide mean is $2.44 \mathrm{~mm}$ decade $^{-1}$, the maximum and minimum values are displayed in the legend.

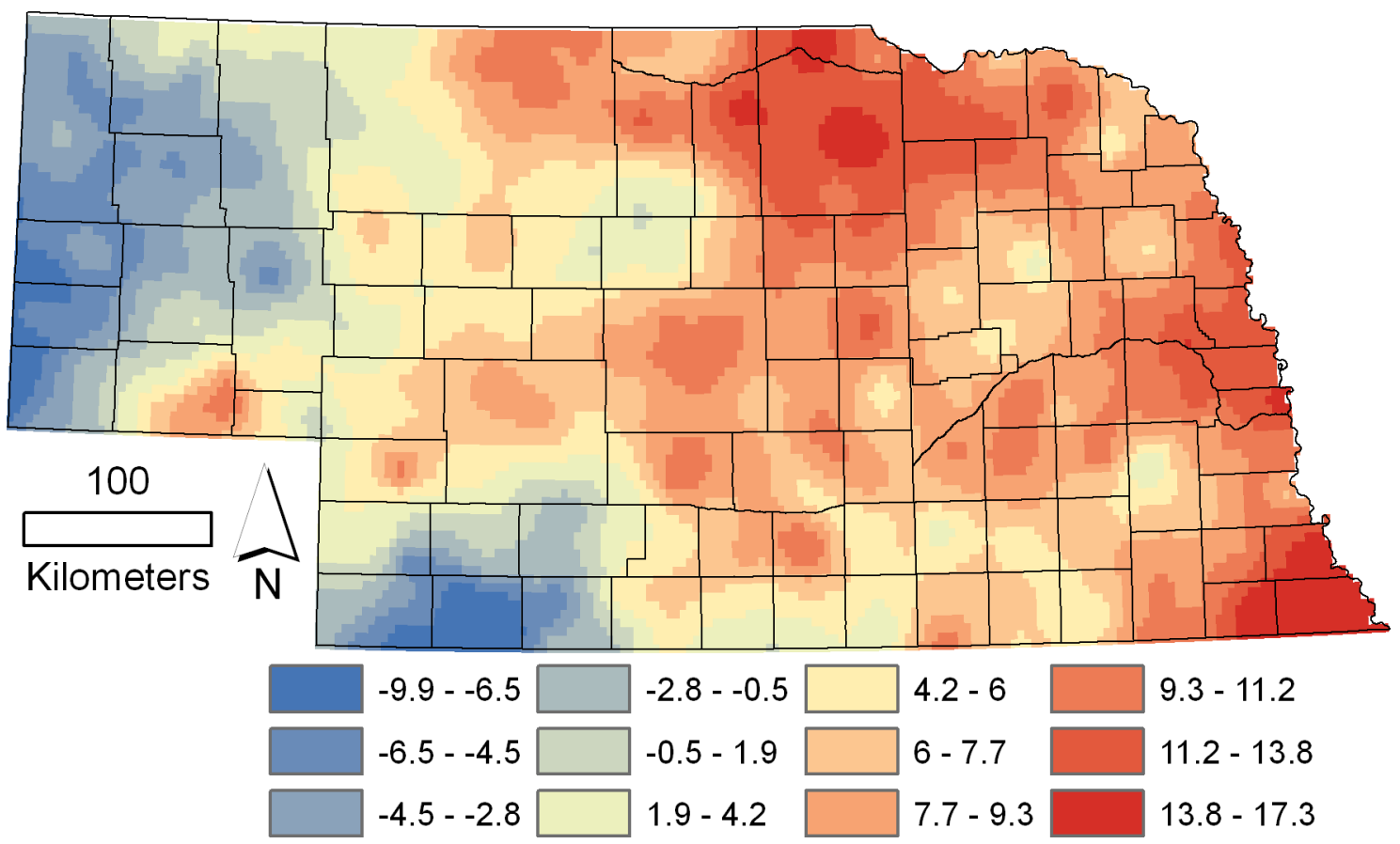

Fig. 13. Annual CR-modeled ET trends (1979-2015) across Nebraska. The state-wide mean is $5.47 \mathrm{~mm}$ decade ${ }^{-1}$, the maximum and minimum values are displayed in the legend.

Table 1

Basic statistics of the annual (1979-2015) state-wide means (Fig. 15) in Nebraska.

\begin{tabular}{|c|c|c|c|c|}
\hline & Mean & Standard deviation & Change per decade & Mann-Kendall $p$-value \\
\hline$T_{a}\left({ }^{\circ} \mathrm{C}\right)$ & 9.57 & 0.82 & +0.1 & 0.63 \\
\hline$T_{d}\left({ }^{\circ} \mathrm{C}\right)$ & 1.37 & 0.7 & +0.2 & $0.086^{* *}$ \\
\hline$P\left(\mathrm{~mm} \mathrm{yr}^{-1}\right)$ & 597 & 97.8 & +2.44 & 0.66 \\
\hline $\mathrm{ET}\left(\mathrm{mm} \mathrm{yr}^{-1}\right)$ & 538 & 43.28 & +5.47 & $0.006^{*}$ \\
\hline ET ratio (\%) & 91.7 & 10.8 & +0.86 & 0.38 \\
\hline$Q\left(\mathrm{~mm} \mathrm{yr}^{-1}\right)$ & 49.7 & 17.54 & -2.81 & 0.39 \\
\hline
\end{tabular}

${ }^{*}$ Trend is significant at the $5 \%$ level.

** Trend is significant at the $10 \%$ level (Hamed and Rao, 1998). 


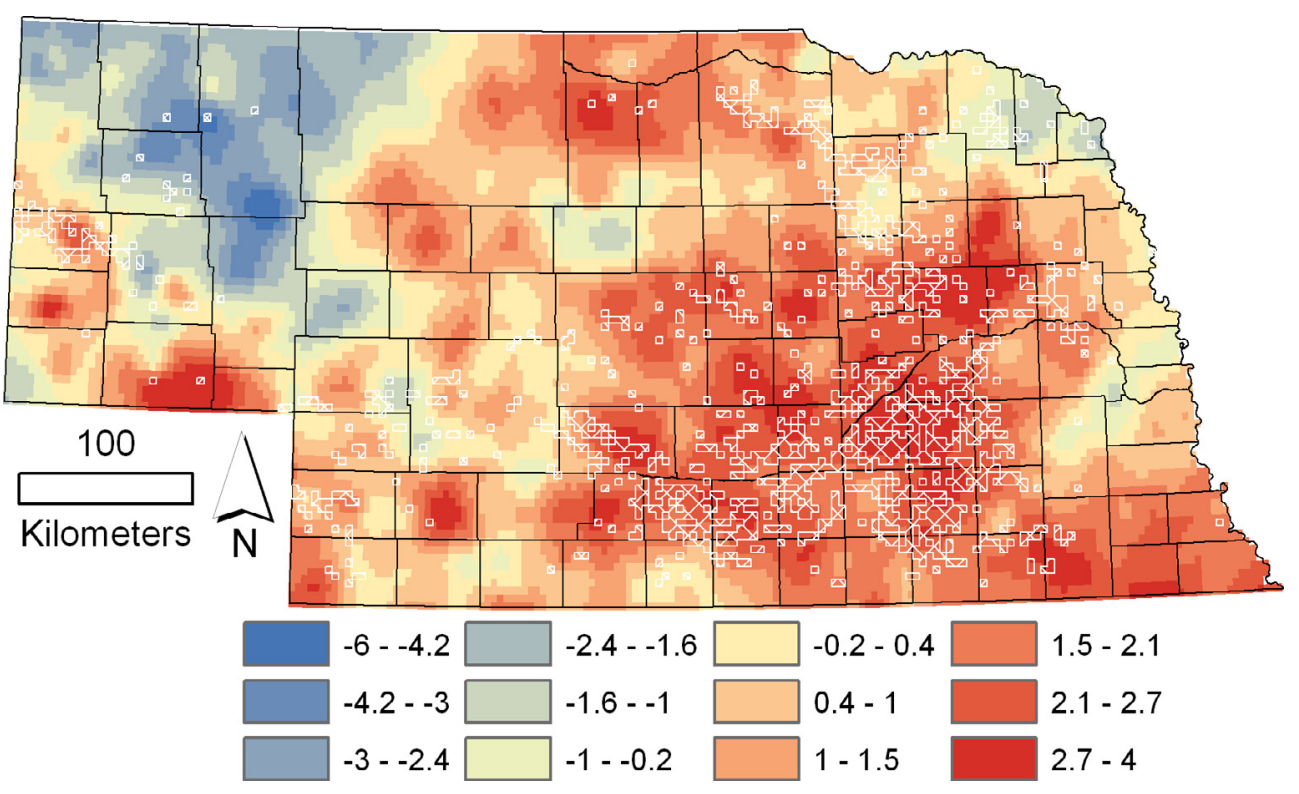

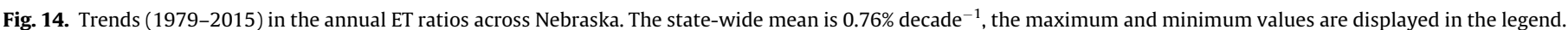
Within the marked cells more than $75 \%$ of the land is irrigated (Brown and Pervez, 2014).

precipitation rate by $23 \mathrm{~mm} \mathrm{yr}^{-1}$ but also yields a declining statewide ET trend of $-2.6 \mathrm{~mm}$ decade $^{-1}$ instead of the here derived more than double (i.e., $5.47 \mathrm{~mm}$ decade $^{-1}$ ) positive trend, in perfect match with the observed state-wide precipitation and streamflow trends. For more details on the US-wide NARR ET rate validations, please refer to Szilagyi (2017b). The CR-based ET rates are not only more accurate than the NARR values, but they require only generally available atmospheric (air- and dew-point temperature, wind velocity) and radiation data, without additional information of land and vegetation properties required by the NARR LSM.

Another interesting finding beside a possible causality between declining precipitation rates and expanding irrigation projects is that with increasing precipitation rates overall, the ET ratios should have declined as a larger proportion of precipitation is expected to run off over wetter soils than dry ones, but instead the ET ratios increased over the large majority of the state's area, at a state-wide average rate of $0.76 \%$ decade $^{-1}$ from the grid-point trends of the annual ET ratios (Fig. 14), and at a rate of $0.54 \%$ decade $^{-1}$ from the $5.47 \mathrm{~mm}^{\text {decade }}{ }^{-1}$ ET and 2.44 $\mathrm{mm}$ decade $^{-1}$ precipitation trends (Table 1 ). This latter rate of ET ratio was obtained as

$\frac{100 \Delta\left(\frac{E T}{P}\right)}{3.7}=\frac{100 \Delta\left(\frac{538 \pm 0.547 * 18.5}{597 \pm 0.244 * 18.5}\right)}{3.7}=\frac{91-89}{3.7}=0.54 \%$ decade

indicating that the ET ratio has increased by at least $2 \%$ (and by $2.8 \%$ from the $0.76 \%$ decade $^{-1}$ value of Fig. 14 ) from a rate of $89 \%$ to $91 \%$ during the study period. When fitting a linear trend-function over the state-wide annual ET ratio values (Fig. 16, Table 1), then this increase becomes even larger, i.e., $0.86 \%$ decade $^{-1}$.

The Budyko Curve (1974) relates the long-term ET ratio of a region to its maximum possible value, assumed when the region is wet, i.e., ET $=E_{w}$ (Porporato et al., 2004; Gerrits et al., 2009), where the latter is mainly a function of the available energy, $R_{n}$, at the surface. In dry climates almost all the precipitation reemerges as ET, thus the ratio is close to unity. The curve predicts a decline in the regionally representative ET ratio under increasing precipitation as the role of runoff becomes more significant. The ratio of $E_{w}$ and $P$ is called an index $(F)$ of aridity. The Budyko curve thus is given by the equation (Budyko, 1974)
$\frac{E T}{P}=\left\{F \tanh \left(F^{-1}\right)\left[1-e^{-F}\right]\right\}^{0.5}$

yielding ET ratios as a monotonically increasing function of aridity, $F$, starting at ET $P^{-1}=0$ at $F=0$ (i.e., super humid conditions), and approaching unity, ET $P^{-1} \rightarrow 1$ as $F \rightarrow \infty$ (i.e., super arid conditions). $E_{w}$ has indeed remained constant $\left(652 \mathrm{~mm} \mathrm{yr}^{-1}\right)$ in Nebraska over the 1979-2015 period, with an imperceptible slope of $0.026 \mathrm{~mm}$ $\mathrm{yr}^{-1}$ decade $^{-1}$. Thus, with the sole increase in the state-wide $P$ value, the state-wide ET ratio should have declined, but it did not, it did the opposite (even if not at a statistically significant rate, see Table 1 ). The exact rate of decline predicted by (11) is not that important $\left(-0.14 \%\right.$ decade $\left.^{-1}\right)$ because there are several alternative expressions for the Budyko curve of (11) (see e.g., Szilagyi and Jozsa, 2009), yielding different rates of decline, but with the shared property that all of them are monotonically increasing functions of F.

As Fig. 14 illustrates, the majority of the largest wide-spread ET ratio increases (in excess of $2 \%$ decade $^{-1}$ ) have taken place over the most extensive irrigated regions of Nebraska where precipitation rates have actually declined (Fig. 12). The observed ET ratio increase is much larger than what could be expected from the Budyko curve (i.e., $<0.5 \%$ decade $^{-1}$ ) due to declining $P$ values alone ( $E_{w}$ stayed constant over irrigated land too), and clearly the result of large-scale, expanding irrigation. The Budyko curve predicts a decrease in ET rates with decreasing $P$ rates, contrary to what is observed, even though the ET ratio increases in both cases. This unusual ET ratio increase over irrigated areas is the main reason that the ET ratio of the whole state has increased under an overall precipitation increase, contrary to predictions of the Budyko-type curves. Note that in the Sand Hills the ET ratio remained constant as $P$ increased by $8.1 \mathrm{~mm}$ decade $^{-1}$ ( $E_{w}$ remained constant) and ET by $6 \mathrm{~mm}$ decade ${ }^{-1}$, again contrary to the Budyko curve. The Sand Hills however has the unique property that surface runoff is practically zero due to the highly porous grass-covered sandy soils and dune formations. As a result, more abundant precipitation just infiltrated into the root-zone instead of having run off on the surface to a stream, and by doing so boosting ET rates and yielding a constant ET ratio which thus could not counter-balance the strong ET ratio-boosting behavior of the irrigated crops on a state-wide basis. 

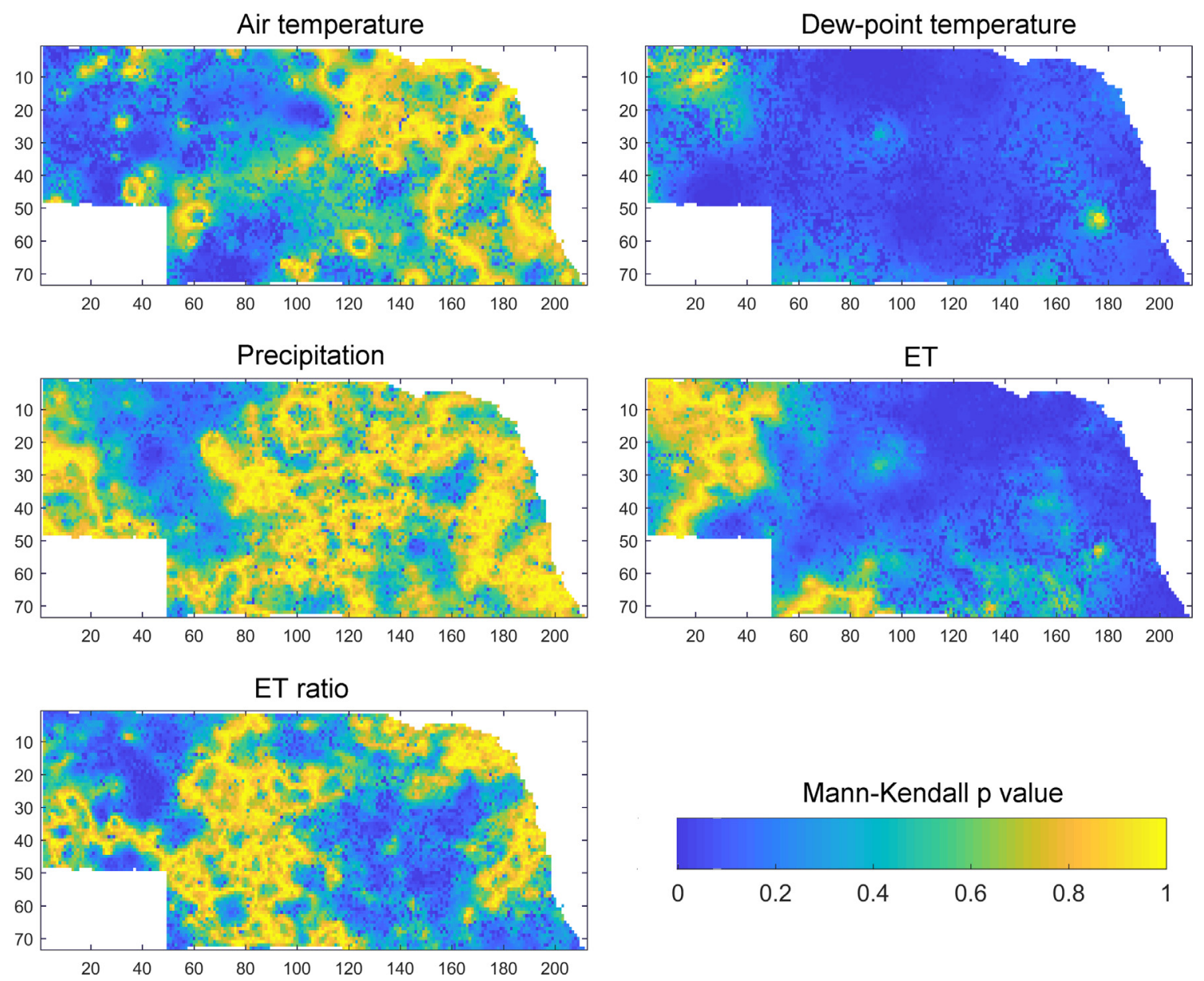

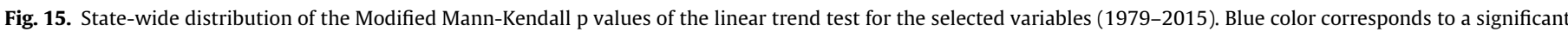
trend.

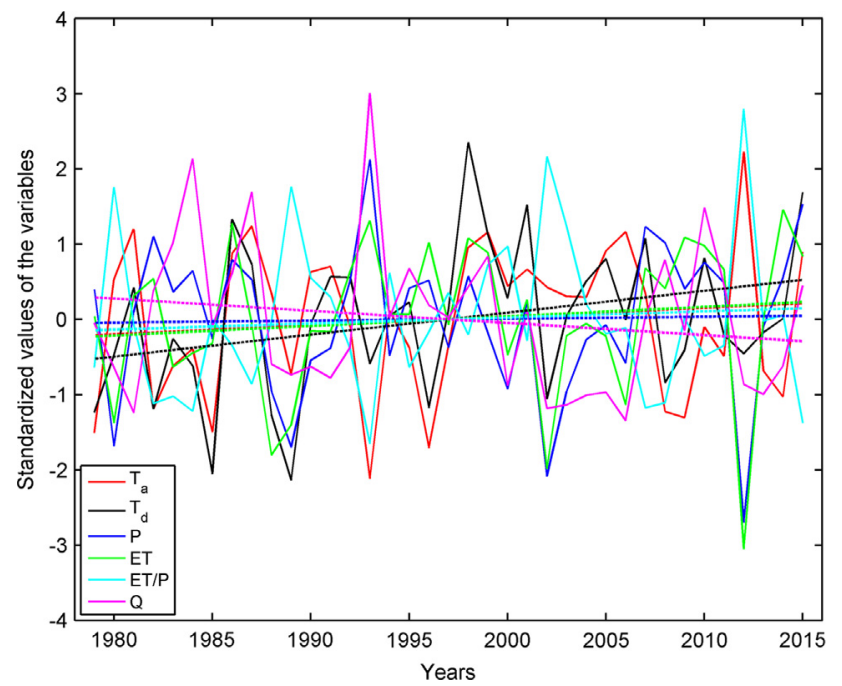

Fig. 16. Standardized time-series (1979-2015) of the annual state-wide means of air-, dew-point temperature, precipitation, ET, ET ratio and streamflow rate in Nebraska. The intermittent lines in matching color are the best-fit linear trends with slopes (\%, in legend's order) of $1.18,2.92,0.25,1.27,0.8$, and -1.6 . See Table 1 for basic statistical properties of the original time-series and the trend-fitting.

Fig. 15 displays the result of the modified (for possible autocorrelation of the time series) Mann-Kendall (Hamed and Rao, 1998) linear trend test at each grid point. The smaller the $\mathrm{p}$ value (i.e., the bluer the color) the more significant the linear trend is. As seen, the dew-point $\left(T_{d}\right)$ trends (predominantly increasing) are the most significant overall across the state, followed by the ET rates. The latter however are significant mostly for the increasing, and not so much for the declining trends. The trends in the ET ratios, in the other hand, can be significant for both increases (in areal extent corresponding to the largest increases in Fig. 14), and decreases, as well.

Finally, Fig. 16 and Table 1 summarize the observed state-wide trends of the variables discussed. $E_{w}, u_{2}$ and $R_{n}$ are not included as they stayed constant during the study period. The strongest trend is found in the ET values (significant at the $5 \%$ level) followed by $T_{d}$, as the two variables with statistically significant trends at the typical 5-10\% level.

\section{Conclusions}

With recent advances in evaporation research (Brutsaert, 2015; Crago et al., 2016; Szilagyi et al., 2017) it is possible to obtain regional ET estimates with an accuracy never seen before and all this with the application of basic meteorological (air- and dew-point temperature, wind velocity, net radiation) variables without information of land surface properties or the need of any kind of parameter calibration. Here the latest calibration-free version (Szilagyi et al., 2017) of the general nonlinear complementary relationship of evaporation was employed for estimating monthly ET trends across Nebraska over the 1979-2015 time period. It was found that ET rates have increased over $3 / 4$ of the area of the state at a 
state-wide average of $5.47 \mathrm{~mm}$ decade $^{-1}$ in accordance with a similar but more moderate $\left(2.44 \mathrm{~mm}\right.$ decade $\left.^{-1}\right)$ state-wide increase in precipitation and an opposite $-2.81 \mathrm{~mm}$ decade $^{-1}$ decline in state- $^{-}$ wide streamflow rates. The estimated ET trend is within $5 \%$ of the difference in the precipitation and streamflow trends.

The state-wide ET increase, surpassing the concurrent increase in precipitation, is the direct result of the about $50 \%$ expansion of irrigated land during the model period, making the state the most intensively irrigated one within the US. Over the most heavily irrigated croplands ET has increased by $7 \mathrm{~mm}$ decade $^{-1}$ despite a $-4.4 \mathrm{~mm}$ decade $^{-1}$ drop in precipitation. It is suspected here that such a suppression of precipitation over irrigated land with a regional extent is not coincidental but a direct result of the regionalscale irrigation process which creates a more stable air stratification over the cooler irrigated crop surfaces. While a teleconnection of large-scale irrigation and increased precipitation downwind has already been reported (Barnston and Schickedanz, 1984; Moore and Rojstaczer, 2002; DeAngelis et al., 2010; Kustu et al., 2011; Harding and Snyder, 2012; Lo and Famiglietti, 2013; Huber et al., 2014) for the coterminous US, the simultaneous local suppression of total precipitation has not, to the best knowledge of the author, yet been recognized to take place within the US, however it has recently been reported for the monsoon region of Northern India (Zeng et al., 2017). The backward trajectory analysis study of Harding and Snyder (2012) has come the closest with its conclusion to the present findings by identifying a suppression of advected moisture over the extensive irrigated fields of Nebraska. They also found that increasing convective available potential energy (coming from irrigation enhanced low-level moisture) typically overwhelms simultaneous surface-cooling-boosted inhibition of vertical convections, yielding a net local increase in precipitation, in contrast to our finding. This suppression of advected precipitation even without leading to decreasing total precipitation rates may exacerbate depletion of the groundwater and/or decline of streamflow rates by not only boosting the total moisture export out of the area via these extensive irrigated areas but simultaneously hindering the import of advective moisture supply, thus creating a positive feedback (Harding and Snyder, 2012) loop for increased irrigation demand.

Irrigation-boosted ET rates have also reversed the trajectory of the state-wide ET ratio which should have been dropping (Budyko curve) due to an increase in state-wide precipitation and constant surface net radiation, but instead it has increased at a rate of $0.54-$ $0.86 \%$ decade $^{-1}$, depending on which method it is calculated by. The freely available Land Surface Model (LSM) ET rates of the North American Regional Reanalysis have completely failed to capture the observed regionally increasing ET trend by yielding a declining trend half the magnitude of the observed increase while at the same time overestimating the period-averaged state-wide ET rate by $15 \%$ (yielding an ET rate in excess of precipitation). The complementary relationship model here captured the state-wide ET rate within $2 \%$.

This study took advantage of the latest developments in evaporation research to investigate how wide-spread land use change can affect the hydrological cycle and demonstrated the capability of the recently advanced complementary relationship of evaporation for estimating regional-scale evapotranspiration rates using widely available meteorological variables only, and all that in a calibration-free manner. It is strongly believed that this approach could prove useful in defining regional-, continental-, and globalscale latent heat fluxes on its own and/or assist the calibration/verification of the presently employed LSMs of the General Circulation Models for an improved understanding of the hydrological cycle and the related climate at the regional, continental or global scale, and climate change itself.

\section{Acknowledgments}

All data used in this study are publicly available from the following sites: waterwatch.usgs.gov (runoff data), www.prism. oregonstate.edu (PRISM data), www.esrl.noaa.gov/psd/data/gridded/data.narr.html (NARR data). Modeled spatially distributed data of this study are available from the author upon request.

\section{References}

Barnston, A.G., Schickedanz, P.T., 1984. The effect of irrigation on warm season precipitation in the Southern Great Plains. J. Clim. Appl. Meteor. 23 (6), 865888

Bates, G.T., Giorgi, F., Hostetler, S.W., 1993. Toward the simulation of the effects of the Great Lakes on regional climate. Mon. Weather Rev. 121, 1373-1387.

Bouchet, R.J., 1963. Evapotranspiration reelle, evapotranspiration potentielle, et production agricole. Ann. Agron. 14, 743-824.

Brown, J.F., Pervez, M.S., 2014. Merging remote sensing data and national agricultural statistics to model change in irrigated agriculture. Agric. Syst. 127. https://doi.org/10.1016/j.agsy. 2014.01.004.

Brutsaert, W., 1982. Evaporation into the Atmosphere: Theory, History and Applications. D. Reider, Dordrecht, Holland.

Brutsaert, W., 2015. A generalized complementary principle with physical constraints for land-surface evaporation. Water Resour. Res. 51, 8087-8093. https://doi.org/10.1002/2015WR017720.

Budyko, M.I., 1974. Climate and Life. Academic, New York.

Changnon, S.A., Jones, D.M.A., 1972. Review of the influences of the Great Lakes on weather. Water Resour. Res. 8, 360-371.

Cox, P.M., Betts, R.A., Jones, C.D., Spall, S.A., Totterdell, I.J., 2000. Acceleration of global warming due to carbon-cycle feedbacks in a coupled climate model. Nature 408, 184-187. https://doi.org/10.1038/35041539.

Crago, R., Szilagyi, J., Qualls, R.J., Huntington, J., 2016. Rescaling of the complementary relationship for land surface evaporation. Water Resour. Res. 52, 8461-8470. https://doi.org/10.1002/2016WR019753.

Crago, R., Qualls, R.J., Szilagyi, J., Huntington, J., 2017. Reply to comment by Ma and Zhang. Water Resour. Res. 53 (7), 6343-6344. https://doi.org/10.1002/ 2017WR021021.

Dai, S., Shulski, M.D., Hubbard, K.G., Takleb, E.S., 2016. A spatiotemporal analysis of Midwest US temperature and precipitation trends during the growing season from 1980 to 2013. Int. J. Climatol. 36, 517-525. https://doi.org/10.1002/ joc. 4354 .

Daly, C., Neilson, R.P., Phillip, D.L., 1994. A statistical topographic model for mapping climatological precipitation over mountainous terrain. J. Appl. Meteor. 33, $140-158$.

DeAngelis, A., Dominguez, F., Fan, Y., Robock, A., Kustu, M.D., Robinson, D., 2010. Evidence of enhanced precipitation due to irrigation over the Great Plains of the United States. J. Geophys. Res. 115. https://doi.org/10.1029/2010JD013892. D15115.

Frankson, R., Kunkel, K., Stevens, L., Shulski, M., 2017. Nebraska State Summary. NOAA Technical Report NESDIS 149-NE, p. 4

Gerrits, A.M.J., Savenije, H.H.G., Veling, E.J.M., Pfister, L., 2009. Analytical derivation of the Budyko curve based on rainfall characteristics and a simple evaporation model. Water Resour. Res. 45. https://doi.org/10.1029/2008WR007308. W04403.

Gleick, P.H., 2003. Water use. Annu. Rev. Environ. Resour. 28, 275-314.

Harding, K.J., Snyder, P.K., 2012. Modeling the atmospheric response to irrigation in the Great Plains. Part II: The precipitation of irrigated water and changes in precipitation recycling. J. Hydromet. 13, 1687-1703. https://doi.org/10.1175/ JHM-D-11-099.1.

Held, I.M., Soden, B.J., 2006. Robust responses of the hydrological cycle to global warming. J. Climate 19, 5686-5699. https://doi.org/10.1175/JCLI3990.1.

Hamed, K.H., Rao, A.R., 1998. A modified Mann-Kendall trend test for autocorrelated data. J. Hydrol. 204, 182-196.

Huber, D.B., Mechem, D.B., Brunsell, N.A., 2014. The effects of Great Plains irrigation on the surface energy balance, regional circulation, and precipitation. Climate 2 , 103-108. https://doi.org/10.3390/cli2020103.

Korus, J.T., Howard, L.M., Young, A.R., Divine, D.P., Burbach, M.E., Jess, J.M., Hallum, D.R., Diffendal, R.F., Joeckel, R.M., 2013. The Groundwater Atlas of Nebraska. Conservation and Survey Division, University of Nebraska-Lincoln.

Kukal, M., Irmak, S., Kilic, A., 2017. Long-term spatial and temporal maize and soybean evapotranspiration trends derived from ground-based and satellitebased datasets over the Great Plains. J. Irrig. Drain. Eng. 143 (9). https://doi.org/ 10.1061/(ASCE)IR.1943-4774.0001212.

Kustu, M.D., Fan, Y., Rodell, M., 2011. Possible link between irrigation in the US High Plains and increased summer streamflow in the Midwest. Water Resour. Res. 47 (3). https://doi.org/10.1029/2010WR010046. W03522.

Lo, M.-H., Famiglietti, J.S., 2013. Irrigation in California's Central Valley strengthens the southwestern U.S. water cycle. Geophys. Res. Lett. 40 (2), 301-306. https:// doi.org/10.1002/grl.50108.

Mahmood, R., Hubbard, K.G., Leeper, R.D., Foster, S.A., 2008. Increase in near-surface atmospheric moisture content due to land use changes: evidence from the observed dewpoint temperature data. Mon. Weather Rev. 136, 1554-1561. 
Mesinger, F., DiMego, G., Kalnay, E., Mitchell, K., Shafran, P.C., Ebisuzaki, W., Jović, D., Woollen, J., Rogers, E., Berbery, E.H., Ek, M.B., Fan, Y., Grumbine, R., Higgins, W., Li, H., Lin, Y., Manikin, G., Parrish, D., Shi, W., 2006. North American Regional reanalysis. Bull. Am. Meteor. Soc. 87, 343-360. https://doi.org/10.1175/BAMS87-3-343.

Monteith, J.L., 1981. Evaporation and surface temperature. Q. J. R. Meteorolog. Soc. $107,1-27$.

Moore, N., Rojstaczer, S., 2002. Irrigation's influence on precipitation: Texas High Plains, U.S.A. Geophys. Res. Lett. 29 (16). https://doi.org/10.1029/2002GL014940.

Mutiibwa, D., Irmak, S., 2013. AVHRR-NDVI-based crop coefficients for analyzing long-term trends in evapotranspiration in relation to changing climate in the $U$. S High Plains. Water Resour. Res. 49, 231-244. https://doi.org/10.1029/ 2012WR012591.

Penman, H.L., 1948. Natural evaporation from open water, bare soil, and grass. Proc. R. Soc. London A193, 120-146.

Porporato, A., Daly, E., Rodriguez-Iturbe, I., 2004. Soil water balance and ecosystem response to climate change. Am. Nat. 164 (5), 625-632. https://doi.org/10.1086/ 424970.

Priestley, C.H.B., Taylor, R.J., 1972. On the assessment of surface heat flux and evaporation using large-scale parameters. Mon. Weather Rev. 100 (2), 81-92.

Szilagyi, J., 1999. Streamflow depletion investigations in the Republican River basin: Colorado, Nebraska, and Kansas. J. Environ. Syst. 27 (3), 251-263.

Szilagyi, J., 2001. Identifying the cause of declining flows in the Republican River USA. J. Water Resour. Plann. Manage. 127 (4), 244-253.

Szilagyi, J., 2014a. MODIS-aided water balance investigations in the Republican River basin USA. Period. Polytech.-Civil Eng. 58 (1), 33-46. https://doi.org/ 10.3311/PPci.2132.

Szilagyi, J., 2014b. Temperature corrections in the Priestley-Taylor equation of evaporation. J. Hydrol. 519, 455-464. https://doi.org/10.1016/j.jhydrol.2014. 07.040.

Szilagyi, J., 2015. Complementary-relationship-based 30-year normals (1981-2010) of monthly latent heat fluxes across the contiguous United States. Water Resour. Res. 51, 9367-9377. https://doi.org/10.1002/2015WR017693.

Szilagyi, J., 2017a. Basic meteorological data derived 30-year normals (1981-2010) of actual evapotranspiration rates in Nebraska, USA. Conserv. Bull. 8.
Conservation \& Survey Division, University of Nebraska-Lincoln, ISBN 156161-058-5.

Szilagyi, J., 2017b. A calibration-free robust estimation of monthly land surface evapo-transpiration rates for continental-scale hydrology. Hydrol. Res. 49. https://doi.org/10.2166/nh.2017.078.

Szilagyi, J., Jozsa, J., 2009. Complementary relationship of evaporation and the mean annual water-energy balance. Water Resour. Res. 45. https://doi.org/10.1029/ 2009WR008129. W09201.

Szilagyi, J., Jozsa, J., 2013. MODIS-aided statewide net groundwater-recharge estimation in Nebraska. Ground Water 51 (5), 735-744. https://doi.org/ 10.1111/j.1745-6584.2012.01019.x.

Szilagyi, J., Zlotnik, V., Gates, J., Jozsa, J., 2011a. Mapping mean annual groundwate recharge in the Nebraska Sand Hills USA. Hydrogeol. J. 19 (8), 1503-1513. https://doi.org/10.1007/s10040-011-0769-3.

Szilagyi, J., Kovacs, A., Jozsa, J., 2011b. A calibration-free evapotranspiration mapping (CREMAP) technique. In: Labedzki, L. (Ed.), Evapotranspiration. INTECH, Rijeka, Croatia. ISBN 978-953-307-251-7, http://www intechopen.com/books/show/title/evapotranspiration.

Szilagyi, J. Crago, R. Qualls, RJ., 2016. Testing the generalized complementary relationship of evaporation with continental-scale long-term water-balance data. J. Hydrol. 540, 914-922.

Szilagyi, J., Crago, R., Qualls, R.J., 2017. A calibration-free formulation of the complementary relationship of evaporation for continental-scale hydrology. J. Geophys. Res. Atmos. 122, 264-278. https://doi.org/10.1002/2016JD025611.

Tapley, B.D., Bettadpur, S., Watkins, M., Reigber, C., 2004. The gravity recovery and climate experiment: mission overview and early results. Geophys. Res. Lett. 31 (L09607), 472. https://doi.org/10.1029/2004GL019920.

United States Department of Agriculture 2012. Census of Agriculture, https://www agcensus.usda.gov/Publications/2012/, last accessed June 21, 2017.

Toth, J., 1963. A theoretical analysis of groundwater flow in small drainage basins. J. Geophys. Res. 68, 4795-4812.

Zeng, Y., Xie, Z., Zou, J., 2017. Hydrologic and climatic responses to global anthropogenic groundwater extraction. J. Climate 30 (1), 71-90. 